University of Nebraska - Lincoln

DigitalCommons@University of Nebraska - Lincoln

Distribution, speciation, and transport of mercury in streamsediment, stream-water, and fish collected near abandoned mercury mines in southwestern Alaska, USA

John E. Gray

U.S. Geological Survey

Peter M. Theodorakos

U.S. Geological Survey

Elizabeth A. Bailey

U.S. Geological Survey

Ralph R. Turner

Frontier Geosciences

Follow this and additional works at: https://digitalcommons.unl.edu/usgsstaffpub

Part of the Earth Sciences Commons

Gray, John E.; Theodorakos, Peter M.; Bailey, Elizabeth A.; and Turner, Ralph R., "Distribution, speciation, and transport of mercury in stream-sediment, stream-water, and fish collected near abandoned mercury mines in southwestern Alaska, USA" (2000). USGS Staff -- Published Research. 395.

https://digitalcommons.unl.edu/usgsstaffpub/395

This Article is brought to you for free and open access by the US Geological Survey at DigitalCommons@University of Nebraska - Lincoln. It has been accepted for inclusion in USGS Staff -- Published Research by an authorized administrator of DigitalCommons@University of Nebraska - Lincoln. 


\title{
Distribution, speciation, and transport of mercury in stream-sediment, stream-water, and fish collected near abandoned mercury mines in southwestern Alaska, USA
}

\author{
John E. Gray, ${ }^{\mathrm{a}, *}$, Peter M. Theodorakos ${ }^{\mathrm{a}}$, Elizabeth A. Bailey ${ }^{\mathrm{b}}$, Ralph R. \\ Turner $^{\mathrm{c}}$ \\ ${ }^{\mathrm{a}}$ US Geological Survey, P.O. Box 25046, MS 973, Denver, CO 80225, USA \\ ${ }^{\mathrm{b}}$ US Geological Survey, 4200 University Drive, Anchorage, AK 99508, USA \\ ${ }^{\mathrm{c}}$ Frontier Geosciences, 414 Pontius North, Seattle, WA 98109, USA
}

Received 27 September 1999; accepted 4 March 2000

\begin{abstract}
Concentrations of total $\mathrm{Hg}, \mathrm{Hg}$ (II), and methylmercury were measured in stream-sediment, stream-water, and fish collected downstream from abandoned mercury mines in southwestern Alaska to evaluate environmental effects to surrounding ecosystems. These mines are found in a broad belt covering several tens of thousands of square kilometers, primarily in the Kuskokwim River basin. Mercury ore is dominantly cinnabar ( $\mathrm{HgS})$, but elemental mercury $\left(\mathrm{Hg}^{\circ}\right)$ is present in ore at one mine and near retorts and in streams at several mine sites. Approximately $1400 \mathrm{t}$ of mercury have been produced from the region, which is approximately $99 \%$ of all mercury produced from Alaska. These mines are not presently operating because of low prices and low demand for mercury. Stream-sediment samples collected downstream from the mines contain as much as $5500 \mu \mathrm{g} / \mathrm{g} \mathrm{Hg}$. Such high $\mathrm{Hg}$ concentrations are related to the abundance of cinnabar, which is highly resistant to physical and chemical weathering, and is visible in streams below mine sites. Although total $\mathrm{Hg}$ concentrations in the stream-sediment samples collected near mines are high, $\mathrm{Hg}$ speciation data indicate that concentrations of $\mathrm{Hg}$ (II) are generally less than $5 \%$, and methylmercury concentrations are less than $1 \%$ of the total $\mathrm{Hg}$. Stream waters below the mines are neutral to slightly alkaline $(\mathrm{pH}$ 6.8-8.4), which is a result of the insolubility of cinnabar and the lack of acid-generating minerals such as pyrite in the deposits. Unfiltered stream-water samples collected below the mines generally contain 500-2500 ng/1 Hg; whereas, corresponding stream-water samples filtered through a $0.45-\mu \mathrm{m}$ membrane contain less than $50 \mathrm{ng} / \mathrm{l} \mathrm{Hg}$. These stream-water results indicate that most of the $\mathrm{Hg}$ transported downstream from the mines is as finely-suspended material rather than dissolved $\mathrm{Hg}$. Mercury speciation data show that concentrations of $\mathrm{Hg}$ (II) and methylmercury in stream-water samples are typically less than $22 \mathrm{ng} / \mathrm{l}$, and generally less than $5 \%$ of the total $\mathrm{Hg}$. Muscle samples of fish collected downstream from mines contain as much as $620 \mathrm{ng} / \mathrm{g} \mathrm{Hg}$ (wet wt.), of which $90-100 \%$ is
\end{abstract}

\footnotetext{
* Corresponding author.
} 
methylmercury. Although these $\mathrm{Hg}$ concentrations are several times higher than that in fish collected from regional baseline sites, the concentration of $\mathrm{Hg}$ in fish is below the $1000 \mathrm{ng} / \mathrm{g}$ action level for edible fish established by the US Food and Drug Administration (FDA). Salmon contain less than $100 \mathrm{ng} / \mathrm{g} \mathrm{Hg}$, which are among the lowest $\mathrm{Hg}$ contents observed for fish in the study, and well below the FDA action level. (c) 2000 Elsevier Science B.V. All rights reserved.

Keywords: Mercury; Stream-sediment; Stream-water; Alaska

\section{Introduction}

The primary objective of this study was to determine if weathering of abandoned mercury mines in southwestern Alaska has resulted in any significant effect to surrounding ecosystems, especially fish. Mercury is a heavy metal of environmental concern because elevated concentrations can be toxic to living organisms. Therefore, the presence of abandoned mercury mines is a potential hazard to residents and wildlife when drainage from the mines enters streams and rivers that are part of local ecosystems. Mercury mineral deposits in southwestern Alaska are located in a broad belt containing numerous mercury mines and unmined deposits scattered throughout several tens of thousands of square kilometers, primarily along the Kuskokwim River basin. The Kuskokwim River region is remote and sparsely populated, with fewer than 1000 inhabitants. Some villages are proximal to mines and there are several small villages along the Kuskokwim River downstream from the mercury mines. Furthermore, because the region is remote, densely covered with vegetation, and poorly explored, there are potentially many more mercury deposits in the region that remain to be discovered (Gray et al., 1997).

The dominant environmental concern related to these mercury mines is inorganic mercury in cinnabar ore and elemental mercury remaining at the mine sites that erode into streams and rivers. Under some conditions, a portion of this inorganic mercury may be converted to organic forms of mercury, which are water soluble and can bioaccumulate in the food chain. When organisms are exposed to mercury contamination, mercury generally increases in concentration with increasing trophic position in the food chain (biomagnification). Mercury contents in fish are par- ticularly important because this is the primary pathway of mercury to humans who consume fish. To evaluate environmental concerns at these mercury mines, we measured the concentration of mercury in stream-sediment, stream-water, and fish collected downstream from several of the mines and deposits in southwestern Alaska. We also analyzed these samples for other traceelements (primarily $\mathrm{Sb}, \mathrm{As}, \mathrm{Bi}, \mathrm{Cd}, \mathrm{Cu}, \mathrm{Mo} \mathrm{Pb}$, and $\mathrm{Zn}$ ) to evaluate any additional heavy-metal contamination related to the mines. Synthetic water leach studies were conducted on calcines samples (retorted ore) from some mines to simulate surface leaching. In addition, because most mercury toxicity problems are related to organic mercury compounds, we measured the concentration of $\mathrm{Hg}$ species such as methylmercury $\left(\mathrm{CH}_{3} \mathrm{Hg}^{+}\right)$, dimethylmercury $\left[\left(\mathrm{CH}_{3}\right)_{2} \mathrm{Hg}\right]$, and ionic mercury $[\mathrm{Hg}$ (II)] in a subset of stream-sediment and stream-water samples to evaluate the conversion of inorganic mercury (primarily cinnabar) to organic forms of mercury (primarily methylmercury). It is generally not necessary to measure $\mathrm{Hg}$ species in fish because methylmercury predominates; however, we measured the concentration of methylmercury in approximately $10 \%$ of the fish samples to determine the relative proportion of methylmercury-to-total mercury. Stream-sediment, stream-water, and fish were also collected and chemically analyzed throughout southwestern Alaska where no mercury deposits are known to establish regional geochemical baselines.

\subsection{Geologic and mine site descriptions}

The Alaska mercury belt is part of the circumPacific belt of mercury mineral deposits that follows the western margin of South, Central, and North America, extending through California and southern Alaska, southward to Japan, through the 
Philippines to New Zealand (Bailey et al., 1973). The south-western Alaska deposits are hosted in a variety of sedimentary and igneous rocks, but are primarily found where igneous rocks of Late Cretaceous and early Tertiary age cut interbedded shale and sandstone of Paleozoic and Mesozoic age. The mercury deposits are found in the sedimentary or igneous rocks, or at their contacts. Using geochronology, formation temperatures, and isotopic-tracer studies, Gray et al. (1997) showed that these mercury deposits formed in epithermal, hot-spring environments that were temporally and spatially related to the late Cretaceous and early Tertiary intrusions.

The mineralogy of the southwestern Alaska mercury deposits is dominantly cinnabar $(\mathrm{HgS})$ and stibnite $\left(\mathrm{Sb}_{2} \mathrm{~S}_{3}\right)$, with subordinate realgar (AsS), orpiment $\left(\mathrm{As}_{2} \mathrm{~S}_{3}\right)$, and rare pyrite $\left(\mathrm{FeS}_{2}\right)$ and gold (Cady et al., 1955; Sainsbury and MacKevett, 1965; Gray et al., 1997). Mineralized veins and vein breccias also contain quartz, carbonate, and clay gangue minerals. At one mine, Cinnabar Creek, naturally-occurring elemental mercury $\left(\mathrm{Hg}^{\mathrm{O}}\right)$ is found in ore. However, elemental mercury has been observed at several other mines near the retorts or in stream drainages, which is probably elemental mercury that was released to the surrounding areas during ore retorting. Several of the deposits were mined between the early 1900s until about 1970, but they are not presently in operation because of low prices and low demand for mercury. Approximately $1400 \mathrm{t}$ of mercury has been produced from the region, which is approximately $99 \%$ of all mercury produced from Alaska. Red Devil is the largest mercury mine in Alaska and it has produced approximately $1240 \mathrm{t}$ of mercury. The deposits show a distinct $\mathrm{Hg}-\mathrm{Sb}-\mathrm{As} \pm \mathrm{Au}$ association, generally containing approximately $1-5 \% \mathrm{Hg}$ and as much as $1 \%$ antimony and arsenic, but the deposits are typically depleted in base metals (Gray et al., 1997).

In this study, we visited 17 mercury mines and unmined deposits in the region to evaluate the sites for study. Of these, stream-sediment and stream-water samples were collected from eight sites, but the majority of our work has been at the Red Devil, Cinnabar Creek, and Red Top mines
(Fig. 1). Most of the fish in our study were collected downstream from the Cinnabar Creek mine because it was one of the few localities where we observed fish relatively near a mercury mine. Fish were also collected from larger watersheds near the Mountain Top, Red Top, and Kolmakof mines. In addition, stream sediment, stream water, and fish were collected from 12 other sites distant from mines (8 localities) or upstream from mercury mines (4 localities) to establish regional geochemical baselines (Fig. 1).

At the abandoned mercury mines in Alaska, cinnabar remaining in ore and calcines piles, and elemental mercury around the mill and retort areas are environmental concerns. For example, at the Red Devil mine, there is cinnabar visible in the area of past surface mining in trenches and surface cuts, as well as in the calcines piles (Fig. 2a). Elemental mercury is visible in several places throughout the retort area at the Red Devil site. Similarly, at the Cinnabar Creek mine, there is cinnabar in open-pit cuts, ore and calcines piles (Fig. 2b), and this is the only mine studied where there is naturally-occurring elemental mercury in the ore. At Red Devil, a minimum of $40000 \mathrm{~m}^{3}$ calcines remain on site, while calcines piles at Cinnabar Creek are estimated to contain at least $10000 \mathrm{~m}^{3}$. At both sites, there is probably additional mercury contamination because the sites are significantly overgrown with vegetation, and in these areas, it is difficult to determine the extent and type of surfical deposits. The Red Top mine has been partially remediated, thus, it was difficult to determine the distribution of mercury at this mine site. Calcines at the Red Devil and Cinnabar Creek mines contain as much as $1 \%$ cinnabar suggesting that processing in the rotary furnaces during retorting was not completely efficient. Cinnabar and elemental mercury visible in streams draining the mines clearly indicates that mercury present at these sites is entering local environments and ecosystems.

\subsection{Sample collection methods and chemical analysis}

Stream-sediment samples were collected from channel-bed alluvium that was composited from 


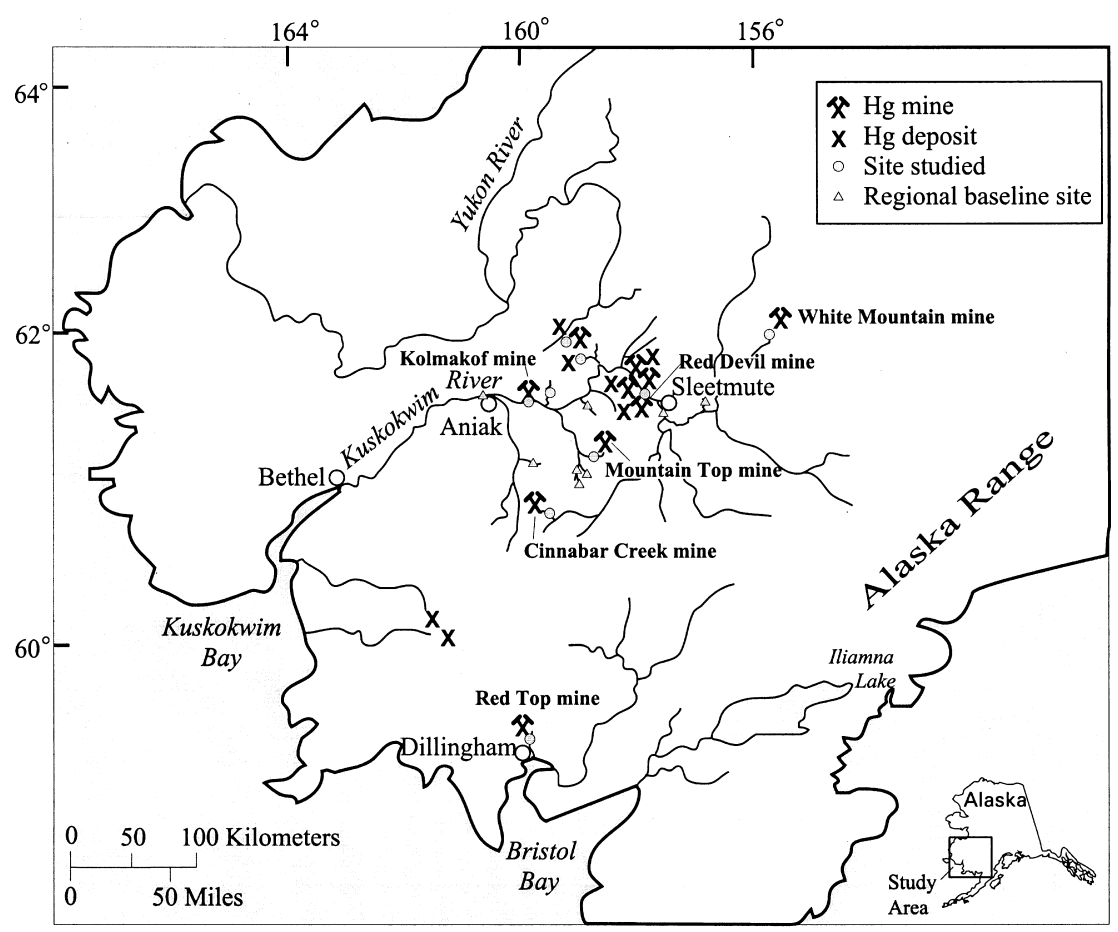

Fig. 1. Location of study area showing the distribution of $\mathrm{Hg}$ mines and deposits in southwestern Alaska, sites studied, and regional baseline sites.

several localities in the channel. Approximately 2 $\mathrm{kg}$ of stream sediment was screened to minus-10 mesh $(2 \mathrm{~mm})$ and collected in a stainless steel gold pan and saved as the sediment sample. Calcines were collected as grab samples that were not sieved in the field; these samples were used for laboratory synthetic leaching studies. Prior to analysis, the stream-sediment and calcines samples were air-dried. Sediment samples were sieved to minus- 80 -mesh $(0.18 \mathrm{~mm})$, and pulverized to less than 100 mesh $(0.15 \mathrm{~mm})$. Both filtered and unfiltered stream-water samples were collected for analysis. All filtered samples were passed through a $0.45-\mu \mathrm{m}$ membrane. Water samples for $\mathrm{Hg}$ analysis were collected in pre-cleaned, glass bottles and preserved with ultra-pure nitric acid and potassium dichromate (total $\mathrm{Hg}$ analyses) or ultra-pure hydrochloric acid (Hg species analyses). Water samples collected for other chemical analyses were collected in pre-cleaned, polypropylene bottles, and preserved with ultra-pure nitric acid. Stream-water characteristics such as $\mathrm{pH}$, conduc- tivity, alkalinity, turbidity, temperature, $\mathrm{Fe}^{2+}$, and dissolved oxygen were measured at each sample site. The sampled sediment bed-load and stream water are clearly representative of upstream sources, but fish are migratory (especially salmon) and may move to and from other locations. However, the objective of the fish sampling was to evaluate potential mining related mercury contamination by collecting fish near the mines and from regional baseline sites.

Fish were collected using angling techniques. Generally, several fish (usually 3-8) were collected from a single site. Arctic grayling and Dolly Varden are common freshwater fish in southwestern Alaska. Arctic grayling (Thymallus arcticus) was the most common in the study area and represents the majority of the fish sampled. Dolly Varden (Salvelinus malma) were collected from some streams when grayling were rare or absent. Chum salmon (Oncorhynchus keta), Coho salmon (Oncorhynchus kisutch), Chinook salmon (Oncorhynchus tshawytscha), and Northern pike 


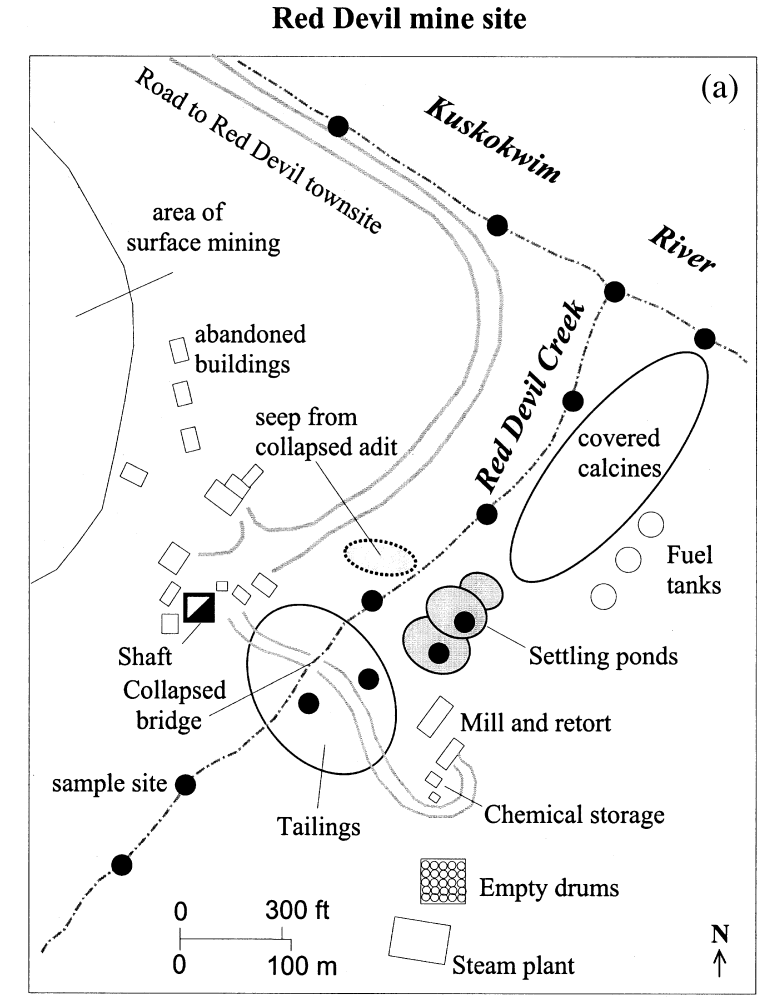

\section{Cinnabar Creek mine site}

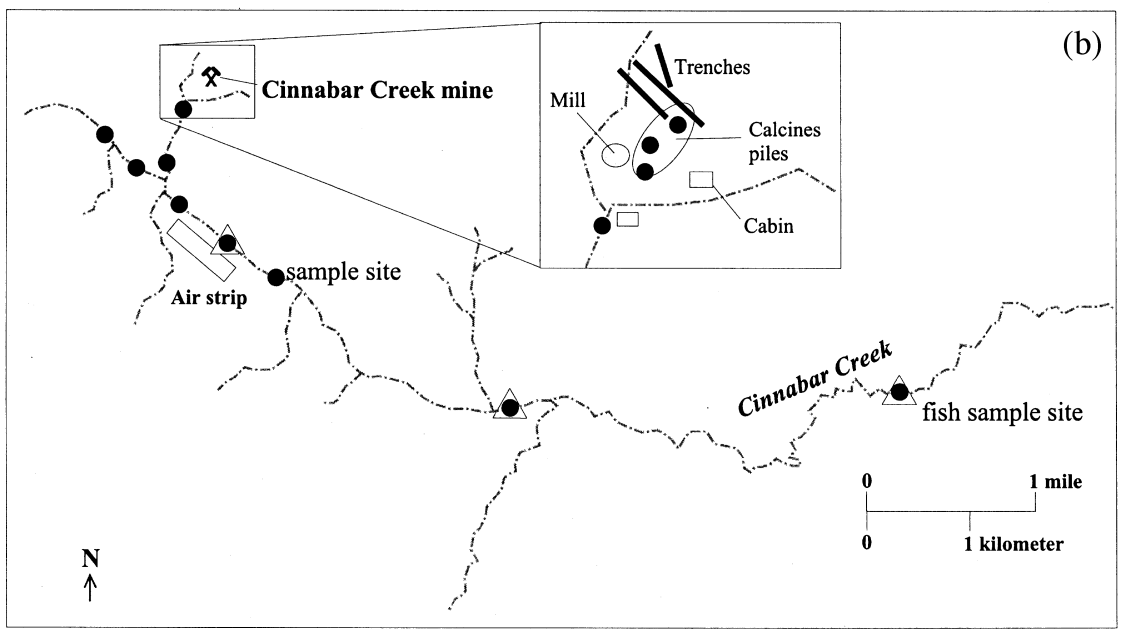

Fig. 2. Plan view of the Red Devil (a) and Cinnabar Creek (b) mines showing the location of sample sites studied in 1996 . The primary environmental concern of these mines is cinnabar and elemental mercury that erodes into local streams. 
(Esox lucius) were collected from streams near some mines and from large rivers in the study area. These fish were collected because they are commonly consumed by residents and sport fishermen in the area. Several fish of all species were collected from streams and rivers distant from $\mathrm{Hg}$ mines to evaluate regional $\mathrm{Hg}$ baseline concentrations. Collected fish were dissected and muscle (fillets) and liver samples were saved for chemical analysis.

Mercury was measured in the stream-sediment, stream-water, calcine leachates, and fish samples using cold-vapor atomic absorption spectrophotometry (CVAAS) techniques modified from Kennedy and Crock (1987), O'Leary (1995), or by a cold-vapor atomic fluorescence spectrometry (CVAFS) technique developed by Bloom and Fitzgerald (1988). In addition to $\mathrm{Hg}$, the streamsediment samples were analyzed for $\mathrm{Sb}, \mathrm{As}, \mathrm{Bi}$, $\mathrm{Cd}, \mathrm{Cu}, \mathrm{Mo}, \mathrm{Pb}$, and $\mathrm{Zn}$ by inductively coupled plasma-atomic emission spectroscopy (ICP-AES) using the method of Motooka (1988); the streamwater, calcine leachates, and fish samples were analyzed for these trace elements using an inductively coupled plasma-mass spectrometry (ICPMS) technique modified from Lamothe et al. (1999). Precision of the CVAAS, CVAFS, ICPMS, and ICP-AES data is $\pm 20 \%$. Methylmercury, dimethylmercury, and mercury (II) species were determined in a portion of the stream-sediment, stream-water, and fish samples by Frontier Geosciences, Seattle, Washington, using CVAFS (Bloom and Fitzgerald, 1988). Mercury speciation results have a precision of $\pm 10 \%$.

\section{Stream-sediment samples}

Stream-sediment samples collected downstream from abandoned mines typically contain greater than $1000 \mu \mathrm{g} / \mathrm{g}$ total $\mathrm{Hg}$ (up to 5500 $\mu \mathrm{g} / \mathrm{g}$ at the Red Devil mine) (Fig. 3). Streamsediment samples collected from regional baseline sites in unmineralized areas and upstream from mines typically contain less than $1.0 \mu \mathrm{g} / \mathrm{g}$ $\mathrm{Hg}$, indicating that the samples collected below the mines have highly elevated $\mathrm{Hg}$ concentrations. These high $\mathrm{Hg}$ concentrations below the
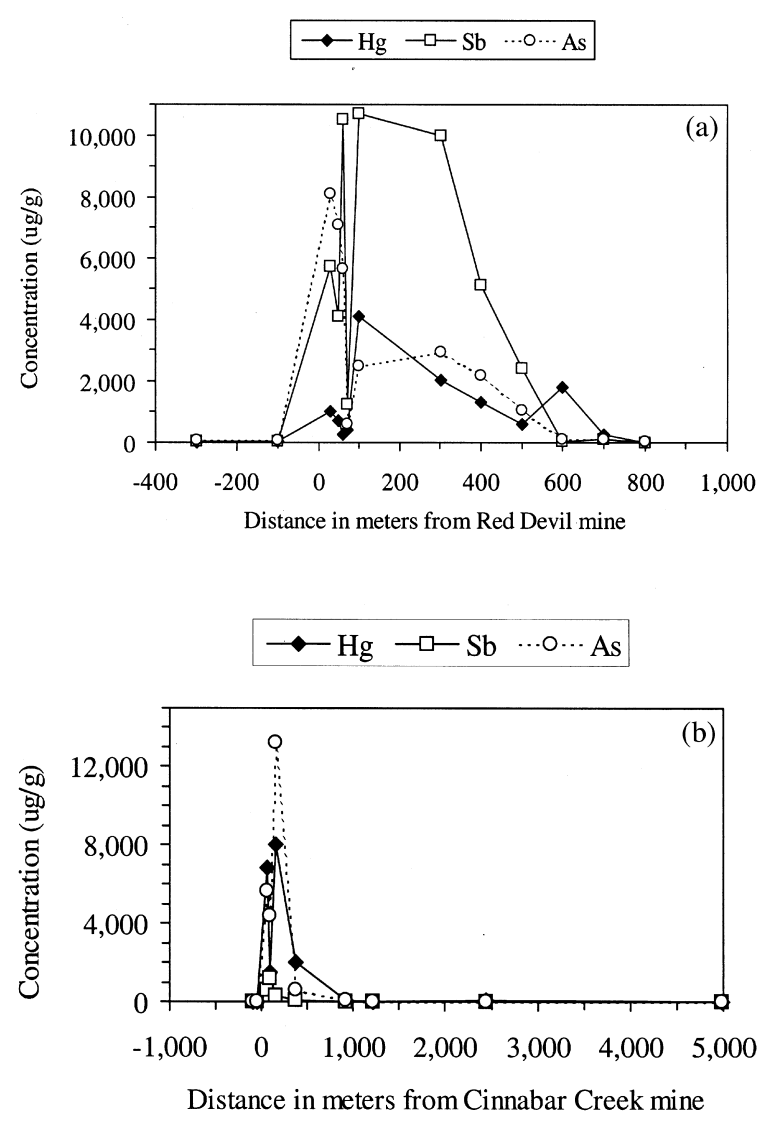

Fig. 3. Plot showing the distribution of $\mathrm{Hg}, \mathrm{Sb}$, and $\mathrm{As}$ in stream-sediment samples collected from the Red Devil (a) and Cinnabar Creek (b) mine sites. Highly elevated concentrations of these elements correlate with cinnabar, stibnite, and realgar that are common in ore in the mercury mines in southwestern Alaska.

mines are due primarily to the presence of the mercury ore-mineral cinnabar that is highly resistant to physical and chemical weathering (Gray et al., 1996). Cinnabar is clearly visible in stream detritus and in cobbles of ore that have eroded into streams at several sites, especially at the Red Devil and Cinnabar Creek mines. Microscopic beads of elemental mercury are also visible with a $10 \times$ hand lens in heavy-mineral concentrate samples collected from streams surrounding the Red Devil, Cinnabar Creek, and Red Top mines. Elemental mercury is much less common than cinnabar at all sites and is estimated to represent less than $0.1 \%$ of the total $\mathrm{Hg}$. As previously 

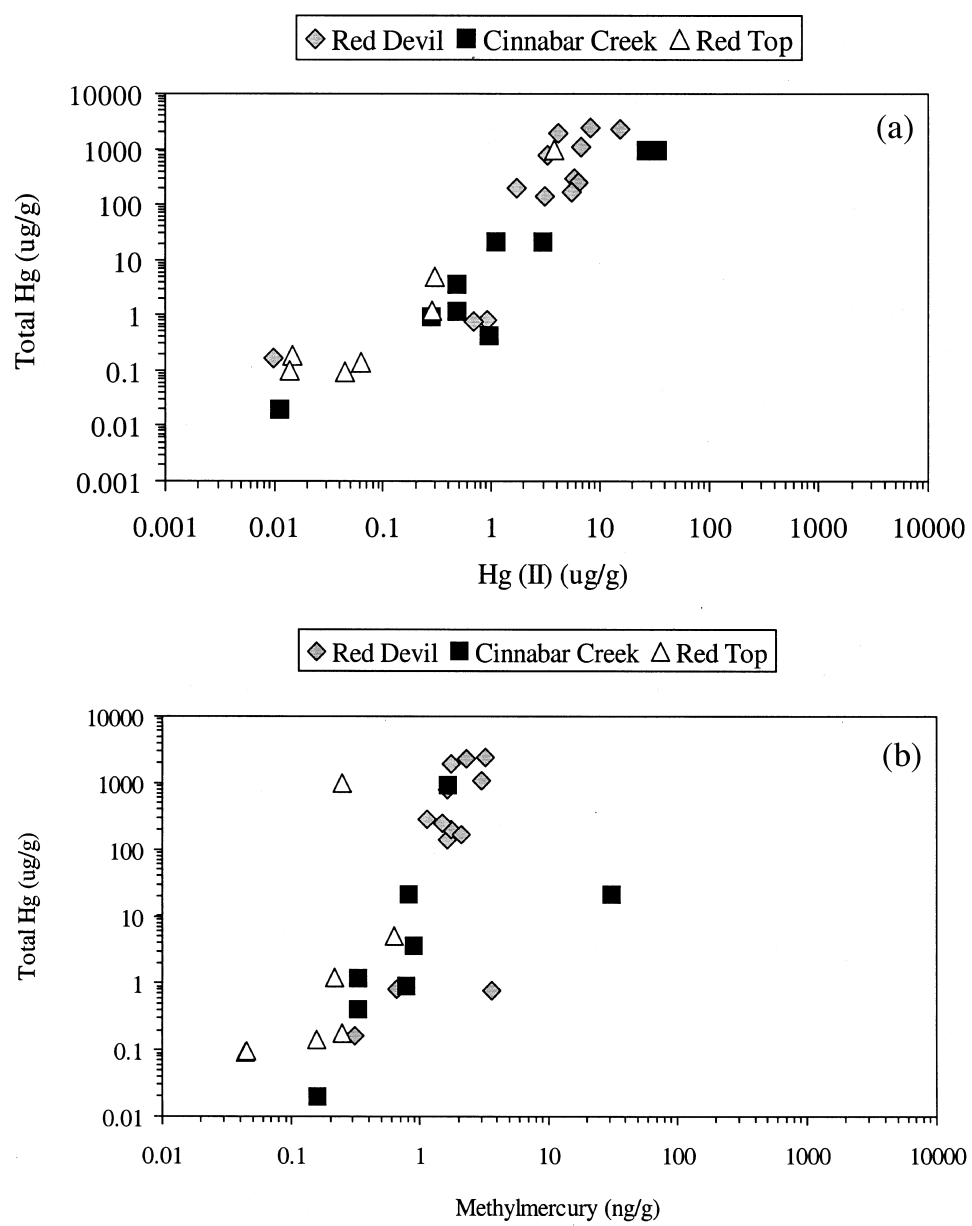

Fig. 4. Plot of total $\mathrm{Hg}$ vs. $\mathrm{Hg}$ (II) (a) and methylmercury (b) in stream-sediment samples collected from the Red Devil, Cinnabar Creek, and Red Top mines. In stream-sediment samples collected downstream from these mines, $\mathrm{Hg}$ (II) generally comprises less than $5 \%$ and methylmercury comprises less than $1 \%$ of the total mercury.

stated, elemental mercury at Cinnabar Creek is naturally-occurring in ore, but at the other sites elemental mercury is a product of ore retorting. In addition to $\mathrm{Hg}, \mathrm{Sb}$ and $\mathrm{As}$ concentrations in stream-sediment samples collected near the mines can be highly elevated. Concentrations of $\mathrm{Sb}$ up to $10700 \mu \mathrm{g} / \mathrm{g}$ and As up to $13250 \mu \mathrm{g} / \mathrm{g}$ have been observed in stream-sediment samples collected near the mines (Fig. 3). High concentrations of $\mathrm{Sb}$ and $\mathrm{As}$ are related to the presence of the minerals stibnite, realgar, and orpiment in ore at these mines.

Mercury speciation studies of stream sediments were conducted at the Red Devil, Cinnabar Creek, and Red Top mines. Although total $\mathrm{Hg}$ concentrations in the stream-sediment samples are high in samples collected downstream from the mines, $\mathrm{Hg}$ (II) concentrations are $<30 \mu \mathrm{g} / \mathrm{g}$ in corresponding samples (Fig. 4a), and generally comprise less than $5 \%$ of the total $\mathrm{Hg}$ (although some baseline samples have a higher proportion of $\mathrm{Hg}$ (II)/total Hg). Similarly, concentrations of the highly toxic methylmercury (Fig. 4b) comprise less than $1 \%$ of the total mercury. Methylmercury concentrations in stream-sediment samples collected from Red Devil Creek and Cinnabar Creek are generally below $5.0 \mathrm{ng} / \mathrm{g}$, and those from the Red Top mine are below $1.0 \mathrm{ng} / \mathrm{g}$ (Fig. 4b). 
However, one sample collected from a flooded part of the creek near a beaver pond, approximately $2-\mathrm{km}$ downstream from the Cinnabar Creek mine, contains $31 \mathrm{ng} / \mathrm{g}$ methylmercury. The higher methylmercury concentration at this site indicates more significant methylation activity in this area, presumably due to higher organic content. Higher methylmercury concentrations at Cinnabar Creek may be related to the higher abundance of elemental mercury at the Cinnabar Creek mine and in the creek downstream vs. that at other sites. Dimethylmercury concentrations in the sediments are below the $0.01 \mathrm{ng} / \mathrm{g}$ detection limit.

\section{Stream-water samples}

Stream-waters draining all mercury mines studied in south-western Alaska are neutral to slightly alkaline, $\mathrm{pH}$ of $6.8-8.4$, indicating that acid-mine drainage from these mines is insignificant. These results are due to the highly resistant nature of cinnabar to chemical and physical weathering and its low solubility in water. Furthermore, pyrite, which is a significant acid-water producing mineral, and problematic at many mines throughout the world, is rare in the mercury mines in Alaska. In addition, total alkalinity was less than $70 \mathrm{mg} / 1$, conductivity was less than $130 \mu \mathrm{s} / \mathrm{cm}, \mathrm{Fe}^{2+}$ was less than $0.1 \mathrm{mg} / \mathrm{l}$, and stream turbidity was less than $10 \mathrm{NTU}$ in this study. Stream water $\mathrm{pH}$, alkalinity, conductivity, $\mathrm{Fe}^{2+}$, and turbidity measured below the mercury mines was similar to that determined for streams from regional baseline sites.

Unfiltered stream-water samples collected below the mercury mines generally contain less than $1800 \mathrm{ng} / \mathrm{l} \mathrm{Hg}$, but may contain as much as $2500 \mathrm{ng} / 1 \mathrm{Hg}$, whereas corresponding streamwater samples filtered through a $0.45-\mu \mathrm{m}$ membrane contain less than $50 \mathrm{ng} / \mathrm{l} \mathrm{Hg}$ (Fig. 5a). These data suggest that most of the mercury transport downstream from the mines is as suspended material, probably particulate cinnabar. Mercury concentrations in these stream waters
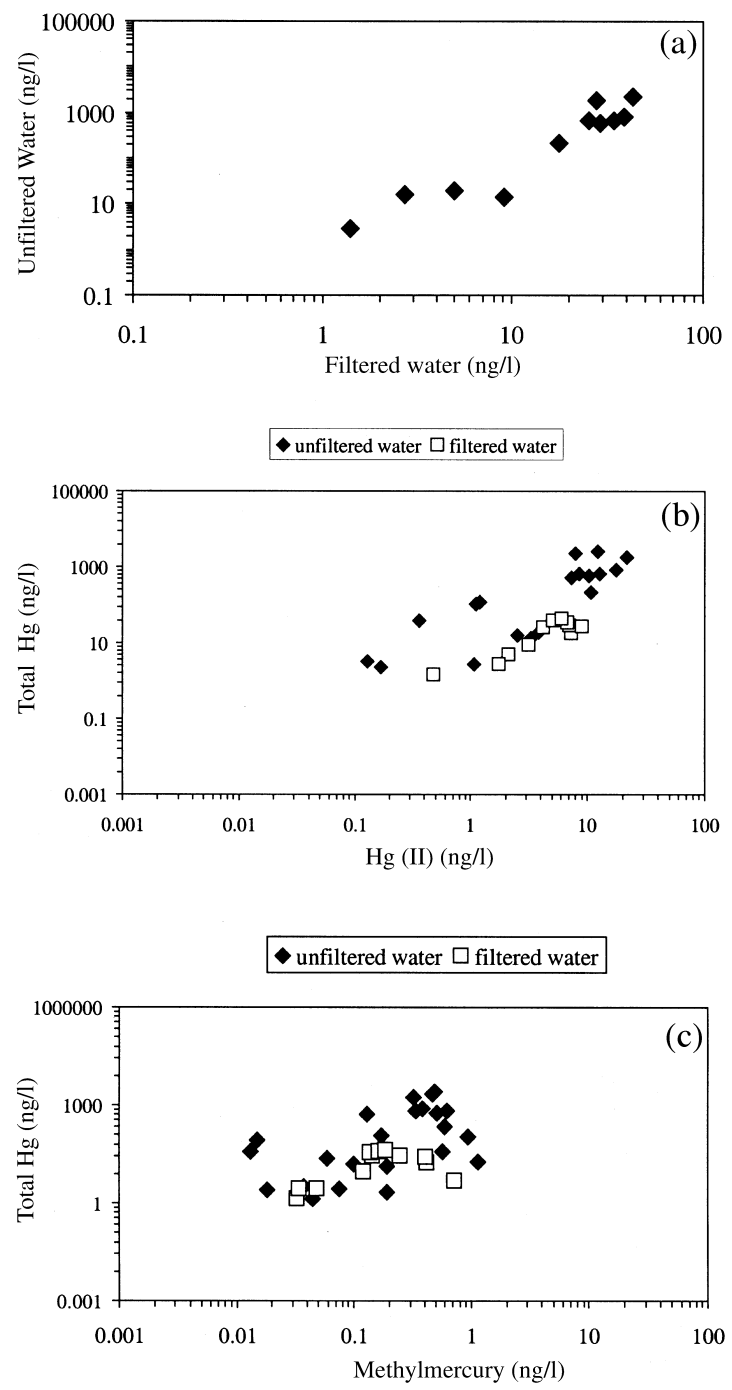

Fig. 5. Diagram showing the concentration of $\mathrm{Hg}$ in unfiltered water vs. that in filtered water $(0.45 \mu \mathrm{m})$ for samples collected from the Red Devil mine (a). Concentrations of $\mathrm{Hg}$ are significantly higher in the unfiltered samples indicating that most of the $\mathrm{Hg}$ transport in water is as suspended particulates rather than dissolved $\mathrm{Hg}$. Plots of total $\mathrm{Hg}$ vs. $\mathrm{Hg}$ (II) (b) and total $\mathrm{Hg}$ vs. methylmercury (c) show that $\mathrm{Hg}$ (II) and methylmercury constitute only a small portion of the total $\mathrm{Hg}$ in water.

are generally below both the $2000 \mathrm{ng} / \mathrm{l}$ drinkingwater standard recommended by the state of Alaska (Alaska Department of Environmental Conservation, 1994) and the $2400 \mathrm{ng} / \mathrm{l}$ maximum concentration recommended by the US Environ- 
mental Protection Agency (EPA). However, Hg concentrations in these mine waters typically exceed the $12 \mathrm{ng} / \mathrm{l}$ concentration that the EPA indicates may result in chronic effects to aquatic life (US Environmental Protection Agency, 1992). When stream-water $\mathrm{Hg}$ concentrations exceed 12 $\mathrm{ng} / \mathrm{l}$, the EPA recommends analyzing edible portions of fish to determine if there has been an adverse effect to fish (see below). Unfiltered stream-water samples collected from regional baseline sites contain less than $10 \mathrm{ng} / \mathrm{l} \mathrm{Hg}$. Although $\mathrm{Hg}$ concentrations in stream-water samples collected downstream from the mines are high, the volume of water discharging from these sites is generally minor. Red Devil Creek has a relative short stream length (Fig. 2a), and discharges approximately $0.02 \mathrm{~m}^{3} / \mathrm{s}$ (estimated by timed drift) into the large Kuskokwim River; the Kuskokwim River discharges approximately 1100 $\mathrm{m}^{3} / \mathrm{s}$ near Red Devil (Wang, 1999). Discharge from Red Devil Creek during spring runoff in May, 1998, was roughly twice as high as in the summer, but is still insignificant compared to the flow in the Kuskokwim River. The discharge volume on Cinnabar Creek approximately $2 \mathrm{~km}$ downstream from the mine was approximately 1 $\mathrm{m}^{3} / \mathrm{s}$ as estimated by timed drift, but there is also significant dilution along Cinnabar Creek because other large tributaries join the creek downstream (Fig. 2b).

Mercury speciation data from the Red Devil, Cinnabar Creek, and Red Top mines indicate that concentrations of $\mathrm{Hg}$ (II) and methylmercury are significant in all stream-water samples. Unfiltered stream-water samples collected below mercury mines contain as much as $22 \mathrm{ng} / \mathrm{l} \mathrm{Hg}$ (II), but comprise less than $5 \%$ of the total $\mathrm{Hg}$ (Fig. $5 b)$. Methylmercury concentrations are less than $1.5 \mathrm{ng} / \mathrm{l}$ and comprise less than $3 \%$ of the total mercury in all unfiltered stream-water samples collected downstream from the mines (Fig. 5c). Dimethylmercury concentrations are below the detection limit $(0.006 \mathrm{ng} / \mathrm{l})$ in all stream-water samples. Similar to the stream-sediment results, the stream-water data suggests relatively minor conversion to methylmercury, probably because particulate cinnabar is the dominant $\mathrm{Hg}$ source and it is not readily converted to organic mercury in oxidized stream water.

\section{Spring-runoff and leach studies of mine wastes}

As result of the remoteness of the study area and associated high operating costs, we were able to conduct spring-runoff studies only at the Red Devil mine in 1998. Therefore, we conducted laboratory water leach studies of calcines samples from the Red Devil and Cinnabar Creek mines, as well as ore samples from several of the mines, using the EPA method 1312 Synthetic Precipitation Leaching Procedure (SPLP) (US Environmental Protection Agency, 1986). The objective of these studies was to simulate surface water leaching of samples collected from the mines. There were 21 samples used in the leach studies. For mine wastes in the 1312 SPLP method, $100 \mathrm{~g}$ of sample was leached with 21 of deionized water acidified to $\mathrm{pH} 4.2$ and the samples were then rotated at $28 \mathrm{rev} . / \mathrm{min}$ for $18 \mathrm{~h}$. The leachate was extracted and filtered through a $0.7-\mu \mathrm{m}$ borosilicate glass filter. The leachates were analyzed for $\mathrm{Hg}$ by CVAAS and for several other trace-metals by ICP-MS (Lamothe et al., 1999) and ICP-AES (Briggs and Fey, 1996). Conductivity and $\mathrm{pH}$ were also measured on the leachates.

Conductivities of the leachates were generally low, ranging from 25 to $235 \mu \mathrm{s} / \mathrm{cm}$, and $\mathrm{pH}$ ranged from 3.3 to 7.8 . The leachate conductivities correspond well with that measured in the field in the open streams below the mines, but $\mathrm{pH}$ was more variable. For example, the lowest $\mathrm{pH}$ (3.3) resulted from leaching of Cinnabar Creek calcines, but stream water along Cinnabar Creek has a $\mathrm{pH}$ of 7.1 to 8.5 . For Red Devil leachate samples, the $\mathrm{pH}$ ranged from 5.4 to 7.8 , but the natural $\mathrm{pH}$ of Red Devil Creek varies from 7.0 to 8.1. The concentrations of $\mathrm{Hg}, \mathrm{Sb}$, and As (the dominant trace-metals for these deposits) are generally higher and more variable in the leachates compared to that in the stream waters collected from Red Devil Creek during the 1998 spring runoff (Fig. 6). For instance, leachates 

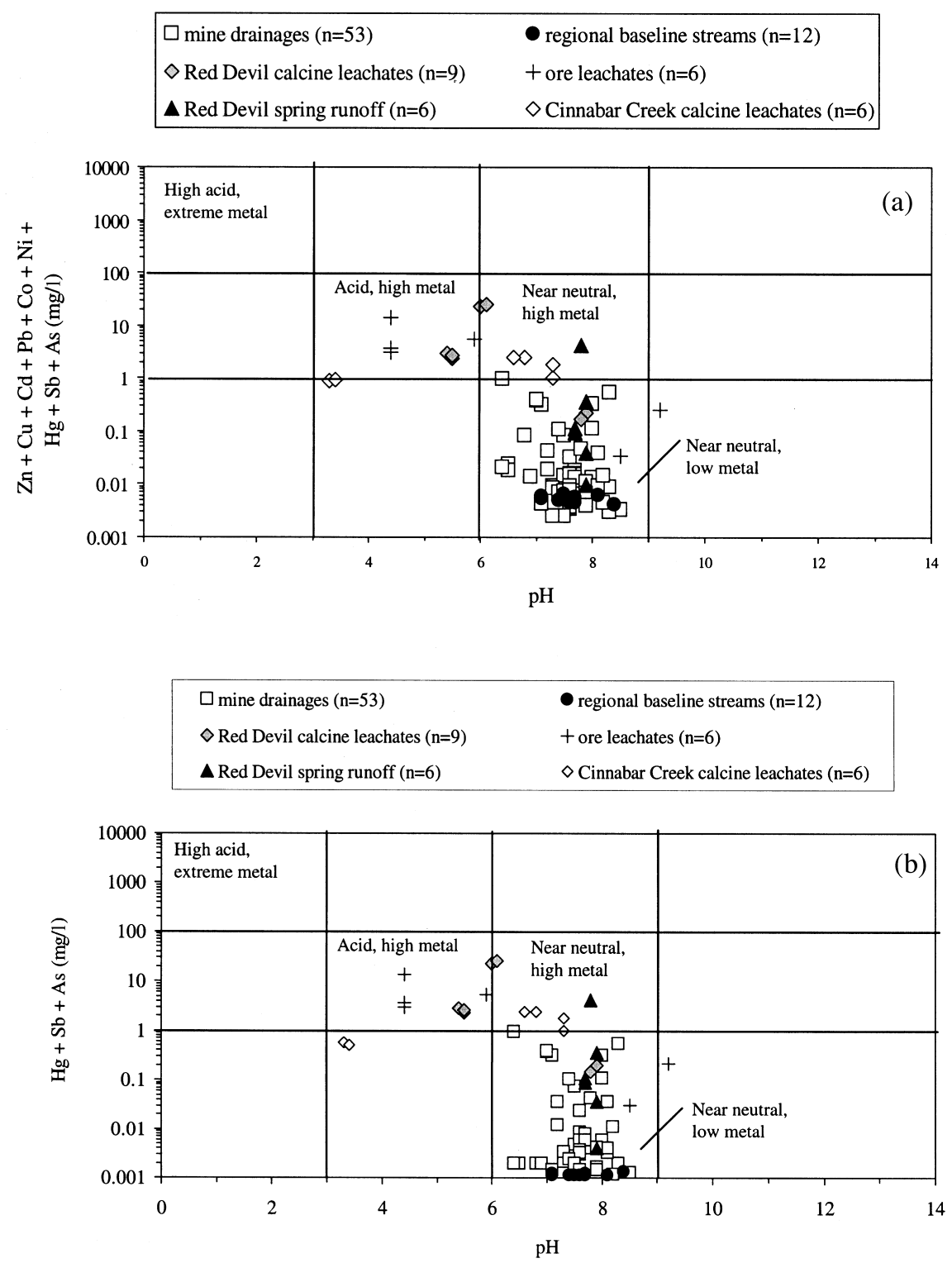

Fig. 6. Scatter diagram of the concentration of the trace metals $\mathrm{Zn}+\mathrm{Cu}+\mathrm{Cd}+\mathrm{Pb}+\mathrm{Co}+\mathrm{Ni}+\mathrm{Hg}+\mathrm{Sb}+\mathrm{As}$ in filtered water vs. $\mathrm{pH}$ (a) and concentration of $\mathrm{Hg}+\mathrm{Sb}+\mathrm{As}$ in filtered water vs. $\mathrm{pH}$ (b) for the mercury mines studied in southwestern Alaska. Contrasting these diagrams shows that $\mathrm{Hg}+\mathrm{Sb}+\mathrm{As}$ are the diagnostic metals in water for these deposits, which is consistent with the ore mineralogy of the deposits. Geochemical data for water collected below mercury mine drainages plot in the near-neutral $\mathrm{pH}$, low metal field. Leach-study results of Hg-ore samples, and calcines collected from the Red Devil and Cinnabar Creek mines, show lower $\mathrm{pH}$ and higher metal concentrations than the mine drainages suggesting that runoff from the mines is naturally diluted downstream.

from the Red Devil mine wastes contain as much as $100 \mu \mathrm{g} / 1 \mathrm{Hg}, 21000 \mu \mathrm{g} / \mathrm{l} \mathrm{Sb}$, and $5800 \mu \mathrm{g} / 1$ As, whereas Red Devil Creek stream water con- tain as much as $2.2 \mu \mathrm{g} / \mathrm{l} \mathrm{Hg}, 4900 \mu \mathrm{g} / \mathrm{l} \mathrm{Sb}$, and $2300 \mu \mathrm{g} / 1$ As. The higher metal concentrations and lower $\mathrm{pH}$ observed in the mine waste 

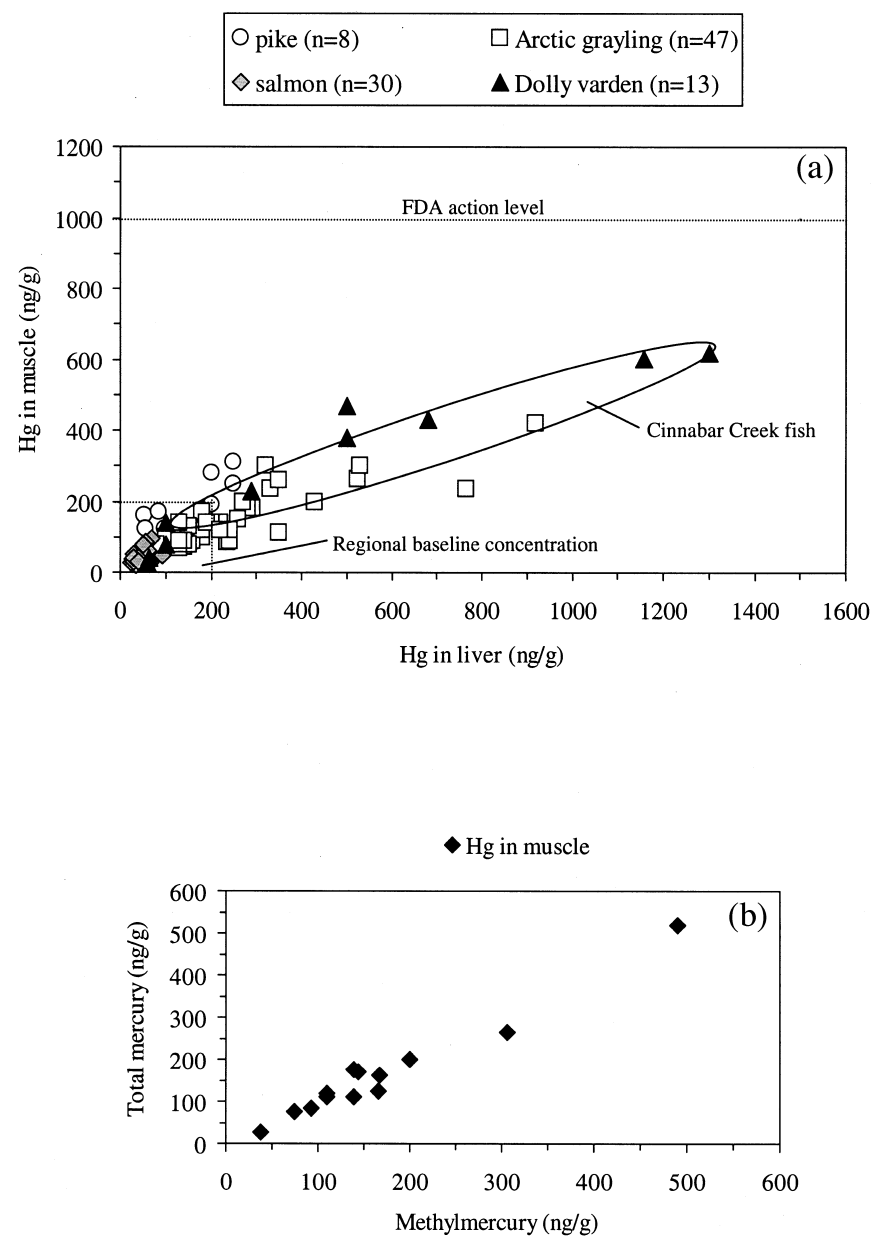

Fig. 7. Plot of $\mathrm{Hg}$ in fish muscle vs. $\mathrm{Hg}$ in fish liver (wet wt. concentrations) for samples collected in this study (a). Fish collected proximal to mercury mines, especially Dolly Varden and Arctic grayling collected from Cinnabar Creek, are elevated over regional geochemical baselines, but all $\mathrm{Hg}$ concentrations in fish are below the FDA action level of $1000 \mathrm{ng} / \mathrm{l} \mathrm{Hg}$ in fish muscle. Mercury concentrations in salmon are among the lowest in the study. The close correlation between total $\mathrm{Hg}$ and methylmercury concentrations in muscle (b) indicates that $90-100 \%$ of the mercury in fish muscle is methylmercury.

leachates suggest that natural runoff is rapidly diluted and buffered downstream from mercury mines.

\section{Fish}

Arctic grayling collected downstream from the mines contain up to $420 \mathrm{ng} / \mathrm{g} \mathrm{Hg}$ (wet wt. muscle) and $920 \mathrm{ng} / \mathrm{g} \mathrm{Hg}$ (wet wt. liver), whereas Dolly Varden contain up to $620 \mathrm{ng} / \mathrm{g} \mathrm{Hg}$ (wet wt. muscle) and $1300 \mathrm{ng} / \mathrm{g} \mathrm{Hg}$ (wet wt. liver). Mer- cury concentrations for these fish are elevated because similar fish collected from baseline streams contain only approximately $200 \mathrm{ng} / \mathrm{g} \mathrm{Hg}$ in muscle (Fig. 7a). The highest $\mathrm{Hg}$ concentrations measured in fish were in relatively small Dolly Varden (e.g. $230 \mathrm{~g}$ and $30 \mathrm{~cm}$ fork length) collected within $2 \mathrm{~km}$ of the Cinnabar Creek mine suggesting a correlation between $\mathrm{Hg}$ contents in fish and distance from the mine. Although freshwater fish collected downstream from the mines contain $\mathrm{Hg}$ concentrations higher than the regional baseline, the $\mathrm{Hg}$ contents in fish 
muscle are below the $1000 \mathrm{ng} / \mathrm{g}$ FDA action level for edible parts of fish (Federal Register, 1979); at this concentration, advisories are posted and the sale of fish is restricted. Mercury contents were also low in muscle samples $(<100 \mathrm{ng} / \mathrm{g})$ of Chum, Coho, and Chinook salmon collected throughout southwestern Alaska. The $\mathrm{Hg}$ concentrations in the salmon were the lowest measured in fish collected in this study and are well below the FDA action level. The low $\mathrm{Hg}$ concentrations in salmon probably result from their migratory nature because during the time they are in fresh water salmon rarely feed. These $\mathrm{Hg}$ results indicate no adverse effect to salmon from the mines, which is important because salmon are the most commonly consumed fish in the region. Mercury contents observed in Northern pike muscle samples were as high as $310 \mathrm{ng} / \mathrm{g}$, but we collected only eight pike in this study and more data are needed to confirm the variation of $\mathrm{Hg}$ in pike in this region.

Methylmercury was measured in 13 fish to determine the proportion of methylmercury-to-total $\mathrm{Hg}$ in the fish. These results indicate that methylmercury comprises more than $90 \%$ of the total mercury (Fig. 7b). Other trace-metals measured in the fish were generally below detection limits.

\section{Summary}

1. Stream-sediment, stream-water, and fish samples collected downstream from abandoned mercury mines in Alaska contain high concentrations of mercury in comparison to regional baseline concentrations in corresponding samples. The ore mineral cinnabar located in the mines is the dominant source of mercury in the stream environment, but minor elemental mercury has been observed at some mine sites and in surrounding streams.

2. Stream-water $\mathrm{pH}$ is near neutral to slightly alkaline $(6.8-8.4)$ in water draining the mercury mines indicating that acid-mine drainage from these mines is insignificant. This is a result of the highly resistant nature of cinnabar to chemical and physical weathering and its low solubility in water, and because pyrite, which is a significant acid-water producing mineral, is rare in the mercury deposits in Alaska.

3. Unfiltered stream-water samples collected below the mercury mines contain elevated $\mathrm{Hg}$ concentrations up to $2500 \mathrm{ng} / \mathrm{l} \mathrm{Hg}$, whereas corresponding stream-water samples filtered through a $0.45-\mu \mathrm{m}$ membrane contain less than $50 \mathrm{ng} / \mathrm{l} \mathrm{Hg}$. These data indicate that suspended material transports most of the mercury downstream from the mines.

4. Concentrations of methylmercury in sediment and water samples indicate minor conversion of inorganic mercury $\left(\mathrm{HgS}\right.$ and $\left.\mathrm{Hg}^{\circ}\right)$ to toxic organic mercury forms such as methylmercury in the stream environment. However, elevated mercury concentrations in freshwater fish collected near the mines indicate that some biologically available mercury is takenup by the fish. The fish probably obtain mercury through food sources or suspended particulates in stream water. However, all of the fish analyzed contain $\mathrm{Hg}$ concentrations below the $1000 \mathrm{ng} / \mathrm{g}$ action level for edible fish recommended by the FDA. Salmon, the most commonly consumed fish in the region, have the lowest $\mathrm{Hg}$ concentrations in fish in this study.

\section{Acknowledgements}

We thank Jim Crock, Phil Hageman, Dave Fey, Paul Lamothe, Al Meier, and Jerry Motooka (USGS) and Nicolas Bloom (Frontier Geosciences) for chemical analyses. Greg Lee and Carter Borden (USGS) assisted with fieldwork. Discussions with Elaine Snyder-Conn (US Fish and Wildlife Service) were helpful throughout the development of this study. The Calista Corporation (Anchorage) provided access to their lands and encouraged these studies. This manuscript was improved by technical comments provided by Steve Wilson and Ian Ridley (USGS). We also thank the editors and two anonymous referees from Science of the Total Environment. 


\section{References}

Alaska Department of Environmental Conservation. Drinking water regulations: State of Alaska. Department of Environmental Conservation report 18-ACC-80, 1994:195.

Bailey EH, Clark AL, Smith RM. Mercury. In: Brobst DA, Pratt WP, editors. United States Mineral Resources. US Geological Survey Professional Paper 820, 1973:401-414.

Bloom NS, Fitzgerald WF. Determination of volatile mercury species at the picogram level by low-temperature gas chromatography with cold-vapour atomic fluorescence detection. Anal Chim Acta 1988;208:151-161.

Briggs PH, Fey DL. Twenty-four elements in natural and acid mine waters by inductively coupled plasma-atomic emission spectrometry. In: Arbogast BF, editor. Analytical methods manual for the Mineral Resource Surveys Program. US Geological Survey Open-File Report 96-525, 1996:95-102.

Cady WM, Wallace RE, Hoare JM, Webber EJ. The central Kuskokwim region. Alaska: US Geological Survey Professional Paper 268, 1955:132.

Federal Register. Action level for mercury in fish, shellfish, crustaceans, and other aquatic animals: comment from the Department of Health, Education, and Welfare, Food and Drug Administration, 1979(44)14:3990-3993.

Gray JE, Gent CA, Snee LW, Wilson FH. Epithermal mercury-antimony and gold-bearing vein deposits of southwestern Alaska. Econ Geol Monogr 1997;9:287-305.

Gray JE, Meier AL, O'Leary RM, Outwater C, Theodorakos PM. Environmental geochemistry of mercury deposits in southwestern Alaska: mercury contents in fish, stream-sediment, and stream-water samples. In: Moore TE, Dumoulin
JA, editors. Geologic studies in Alaska by the US Geological Survey 1994. US Geol Surv Bull 1996;2152:17-29.

Kennedy KR, Crock JG. Determination of mercury in geological materials by continuous flow, cold-vapor, atomic-absorption spectrophotometry. Anal Lett 1987;20:899-908.

Lamothe PJ, Meier AL, Wilson S. The determination of forty four elements in aqueous samples by inductively coupled plasma-mass spectrometry: US Geological Survey Open-File Report 99-151, 1999:14.

Motooka JM. An exploration geochemical technique for the determination of preconcentrated organometallic halides by ICP-AES. Appl Spectrosc 1988;47:1293-1296.

O'Leary RM. The determination of mercury and selenium in eight Argonne Premium coal samples by cold vapor and hydride atomic absorption spectrometry. In: Palmer CA, editor. The chemical analysis of argonne premium coal samples: US Geol Surv Bull, in press, 1995:J1-J11.

Sainsbury CL, MacKevett EM. Quicksilver deposits of southwestern Alaska. US Geol Surv Bull 1965;1187:89.

US Environmental Protection Agency. Test methods for evaluating solid waste. Vol I and II SW-846. 3rd edition. November, 1986. Updates are available through revision 2V, April 4, 1995, 1986.

US Environmental Protection Agency. Water quality standards; establishment of numeric criteria for priority toxic pollutants; states' compliance; final rule. Federal Register, 40 CFR Part 131, v 57 1992;246(60):847-60,916.

Wang B. Spatial distribution of chemical constituents in the Kuskokwim River. Alaska: US Geological Survey WaterResources Investigations Report 99-4177, 1999:33. 